\title{
Assembling the prenylneoflavone system through a Pechmann condensation/Mitsunobu reaction/Claisen rearrangement/olefin cross-metathesis sequence
}

\author{
Oleg A. Lozinski ${ }^{1,2,3} \cdot$ J. Bistodeau ${ }^{2} \cdot$ C. Bennetau-Pelissero ${ }^{4} \cdot$ Vladimir P. Khilya $^{1} \cdot$ S. Shinkaruk ${ }^{2}$
}

Received: 27 November 2019 / Accepted: 21 March 2020 / Published online: 28 April 2020

(c) Springer-Verlag GmbH Austria, part of Springer Nature 2020

\begin{abstract}
The multistep synthesis of a prenylneoflavone through a sequence of the Mitsunobu reaction/Claisen rearrangement/olefin cross-metathesis reaction has been accomplished in 5\% yield over six steps starting from commercially available 3-methoxyacetophenone. The sequence is shown to be compatible with a Pechmann condensation which proved to be a robust and cost-effective method for the assembling of the $\alpha$-pyrone core. The results open doors to a general approach to the prenylneoflavone system starting from phenol and acetophenone derivatives.
\end{abstract}

\section{Graphic abstract}

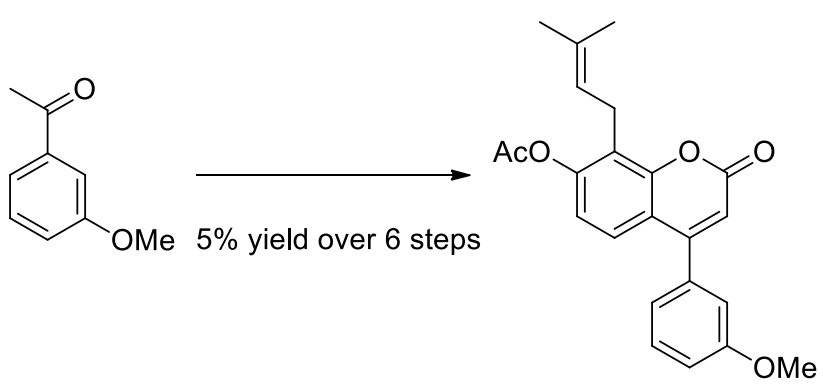

Keywords Prenyl $\cdot$ Flavonoids $\cdot$ Alkenes $\cdot$ Heterocycles $\cdot$ Metathesis

Electronic supplementary material The online version of this article (https://doi.org/10.1007/s00706-020-02584-8) contains supplementary material, which is available to authorized users.

Oleg A. Lozinski

lozinskioleg@gmail.com

1 Taras Shevchenko National University of Kyiv, Kyiv, Ukraine

2 University of Bordeaux, ISM, UMR 5255, CNRS, Bordeaux, France

3 University of Bordeaux, Neurocentre Magendie, UMR 1215, INSERM, Bordeaux, France

4 University of Bordeaux, ARNA, UMR 1212, INSERM/CNRS, Bordeaux, France

\section{Introduction}

Prenyl group plays an important role in the enhancement of bioactivity [1] being responsible for protein-protein binding through the specific attachment to the prenyl binding domains [2]. For a range of oxygen-containing heterocycles, the presence of prenyl group is linked to the increased potency of estrogenic activity profile [3]. Notably, 8-prenylnaringenin (8PN, 1, Fig. 1) is considered to be the most potent estrogenic flavonoid known [4].

In addition, targeting proteases is an effective antiviral strategy in suppressing viral genome replication to cure $\mathrm{CoV}$ infection [5]. Angiotensin-converting enzyme (ACE) inhibitors are blockbusters among protease inhibitors on the market [6]. Zhou et al. confirmed that 2019-nCoV uses the same cell entry receptor-angiotensin-converting enzyme II 
<smiles>[R]c1c(O)c([R])c2c(c1O)C(=O)CC(c1ccc(O)cc1)O2</smiles>

$1 \mathrm{R}=$ prenyl, $\mathrm{R}^{\prime}=\mathrm{H}$;

$4 \mathrm{R}=\mathrm{H}, \mathrm{R}$ '=prenyl;<smiles>CC(C)=CCC=CC=[18O]</smiles><smiles>O=c1c(-c2ccc(O)cc2)coc2cc(O)c([14O])c(O)c12</smiles><smiles></smiles>

$2 \mathrm{R}=$ prenyl; $6 \mathrm{R}=\mathrm{H}$

Fig. 1 Compounds 1, 2, and 4-6

(ACE2) - as SARS-CoV [7]. This represents protease inhibitors as attractive targets in search for the treatment of 2019nCoV. Interestingly, the prenylated derivative of quercetin 2 (Fig. 1) exhibited the highest inhibitory effects on the papain-like protease $\left[\mathrm{PL}^{\mathrm{pro}}\right]$ in $\mathrm{SARS}-\mathrm{CoV}\left(\mathrm{IC}_{50}=3.7 \mu \mathrm{M}\right)$ [5].

A set of prenylation methods have been reported up to date [8]. The prenylneoflavone system assembling is of particular interest due to the fact that neoflavones represent one of the most ubiquitous classes of naturally occurring oxygencontaining heterocycles that still remain poorly investigated.

\section{Results and discussion}

Our studies in the requisite 4-(3-methoxyphenyl)-8-(3-methylbut-2-en-1-yl)-2-oxo-2H-chromen-7-yl acetate (3) synthesis (Scheme 1) commenced with close examination of the strategy and the means of the synthesis that should meet the criteria required in terms of cost-effective and feasible design. The synthetic task falls into two groups of questions: the prenyl group installment and the $\alpha$-pyrone ring assembling, respectively.

Two approaches towards the prenylcoumarin motif are distinguished: (1) starting from salicylic aldehydes and cinnamates through the tandem Claisen rearrangement/Wittig olefination/cyclization sequence [9] and (2) using preformed coumarin skeleton via the Mitsunobu reaction/Claisen rearrangement/olefin cross-metathesis reaction sequence [10]. The latter was used by Tischer and Metz for the synthesis of the naturally occurring 8-prenylnaringenin (1), 6-prenylnaringenin (4), 6-prenylgenistein (5), and 6-prenylquercetin (6) (Fig. 1).

It has drawn our attention as the excellent example of the synergy of up-to-date olefin cross-metathesis reaction and conventionally used the Claisen rearrangement in a single synthetic sequence through which prenyl group can be readily installed.

However, to extend the substrate scope of this approach it may be advantageous to start from aromatic compounds

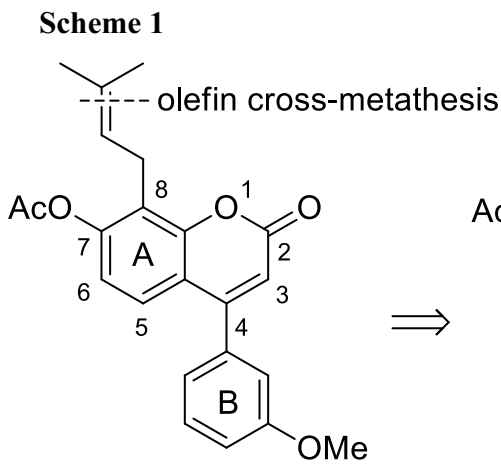

3<smiles>C=C[As](C=C)c1c(OC(C)=O)ccc2c(-c3cccc(OC)c3)cc(=O)oc12</smiles>

12

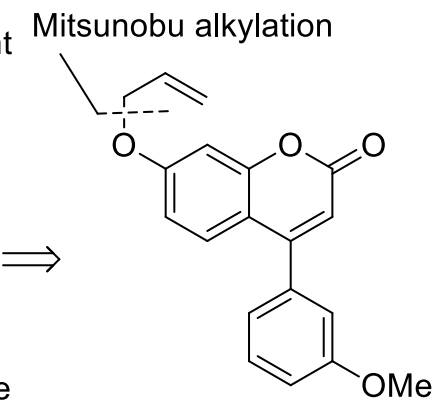

10

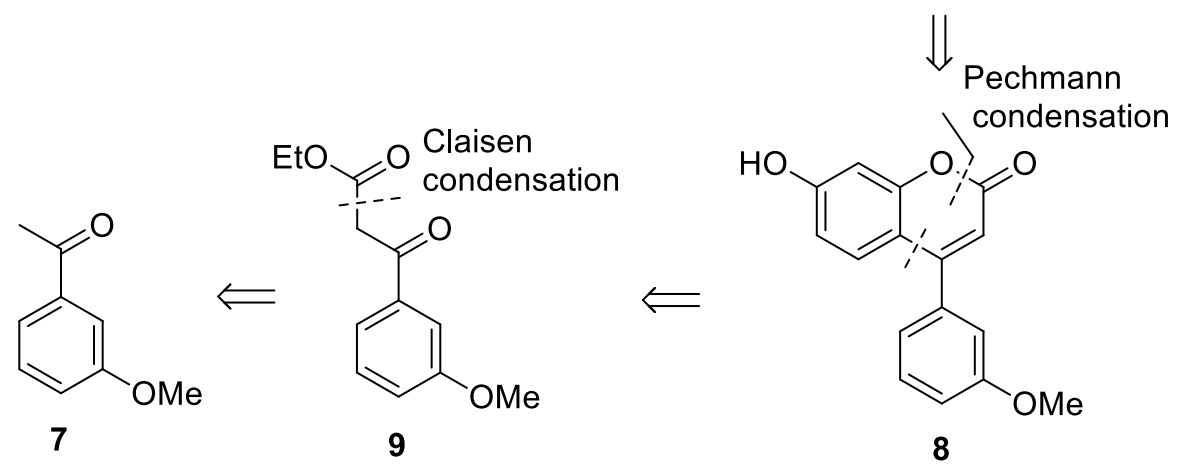


such as phenols. As part of our ongoing research program in the field of the chemistry of oxygen-containing heterocycles [11] we aimed to build a bridge between the conventionally used and the most state-of-the art methods. Thus, we chose the Pechmann condensation to study its compatibility with the Mitsunobu reaction/Claisen rearrangement/olefin crossmetathesis reaction sequence to access prenylneoflavones starting from aromatic compounds such as 3-methoxyacetophenone (7) (Scheme 1).

In view of the presence of multiple reaction centers in two aromatic rings of a neoflavone, its ortho-functionalization must be effectively achieved through the Claisen rearrangement. A series of groups has been reported in the literature as prenyl synthons, namely 2-methylbut-3-en-2-yl, prenyl, and allyl [8].

Nevertheless, the selective Claisen rearrangement is a challenging task because of the isomer formation in the competent Claisen-Cope rearrangement [8]. At the same time, allyl group has been reported to be the versatile synthon of prenyl group in the Mitsunobu reaction/Claisen rearrangement/olefin cross-metathesis reaction sequence [8].

This approach relies upon the Mitsunobu alkylation which is not water sensitive and, therefore, takes an advantage of time-saving benefits compared to a classical alkylation using alkyl halides and bases in a dry solvent. It enables proceeding on the next step without further purification of the coumarin obtained via the Pechmann condensation.

Therefore, the Pechmann condensation/Mitsunobu alkylation/Claisen rearrangement/olefin cross-metathesis reaction sequence represents the approach through which the prenylneoflavone synthesis can be readily achieved in a cheap

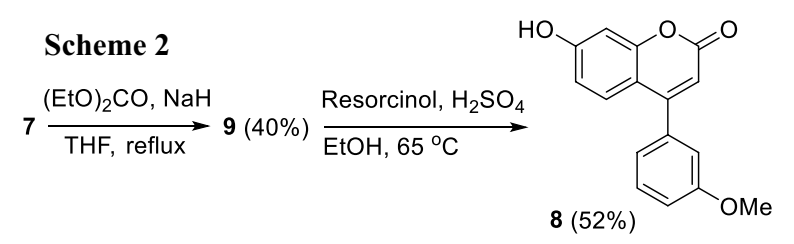

manner employing the idea of the synergy of cost-effective and powerful means to organic synthesis.

The foregoing synthetic blueprint demonstrates the key scissions in the retrosynthesis of the prenylneoflavone $\mathbf{3}$ via the synthetic strategy shown in the Scheme 1.

To assemble the pivotal neoflavone system, the twostep conversion of 3-methoxyacetophenone (7) into 7-hydroxy-4-(3-methoxyphenyl)- $2 \mathrm{H}$-chromen-2-one (8) was effected via the Claisen condensation of 7 into ethyl 3-(3-methoxyphenyl)-3-oxopropanoate (9) in 40\% yield, followed by the Pechmann condensation of 9 with resorcinol in the presence of sulfuric acid to obtain neoflavone $\mathbf{8}$ in 52\% yield (Scheme 2) [12].

With neoflavone $\mathbf{8}$ in hand, our attention turned to prenyl group installment in the neoflavone core. The prenyl group installment strategy relied upon the sequence of the Mitsunobu reaction and the Claisen rearrangement with the following olefin cross-metathesis reaction. Therefore, subsequent treatment of 8 with DIAD, $\mathrm{PPh}_{3}$ in THF at $0{ }^{\circ} \mathrm{C}$ resulted in 7-allyloxy-4-(3-methoxyphenyl)-2 $\mathrm{H}$-chromen-2one (10) formation in $78 \%$ yield (Scheme 3).

In the ${ }^{1} \mathrm{H}$ NMR spectrum of $O$-allyl product 10 recorded in $\mathrm{CDCl}_{3}$ the doublet at $4.61 \mathrm{ppm}$, the doublet of doublet of triplets at 5.34-5.45 ppm and at $6.05 \mathrm{ppm}$ are consistent with OH substitution with allyl moiety.

The Claisen rearrangement proved to be the most challenging step required extensive troubleshooting for reaction conditions optimization. Thermal and Lewis acid catalysis factors are considered [8]. It has been reported that in contrast to the boron trichloride catalyst, upon treatment with $\mathrm{Et}_{2} \mathrm{AlCl}$, a range of substituted allylchlorophenyl ethers bearing electron-withdrawing groups on the aromatic ring undertook the Claisen rearrangement to afford allylchlorophenols in quantitative yields [13].

However, the attempted reaction of 7-allyloxyneoflavone 10 with $\mathrm{Et}_{2} \mathrm{AlCl}$ at the same conditions resulted in dealkylation of 7-allyloxyneoflavone $\mathbf{1 0}$ (Scheme 3, Table 1) to give neoflavone 8 in $87 \%$ yield. Therefore, we chose to proceed

Scheme 3<smiles>[R]Oc1ccc2c(-c3cccc(OC)c3)cc(=O)oc2c1</smiles>

8,10

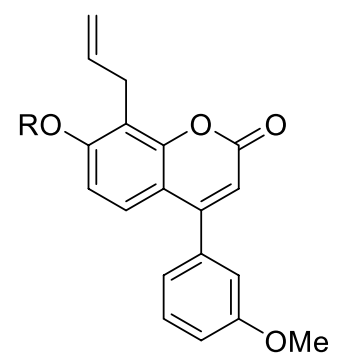

11,12

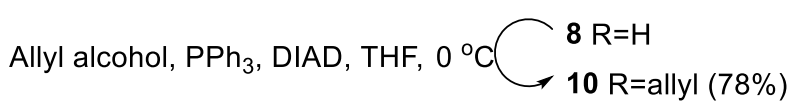

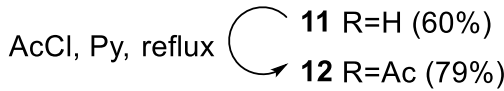


Table 1 The optimization of the reaction conditions of the Claisen rearrangement of $O$-allyl product $\mathbf{1 0}$

\begin{tabular}{lllllll}
\hline Entry & $T /{ }^{\circ} \mathrm{C}$ & Time/h & Solvent & $W$ & Catalyst & $\begin{array}{l}\mathbf{1 1} \\
\text { Yield/\% }\end{array}$ \\
\hline 1 & r.t & 24 & Toluene & - & $\mathrm{Et}_{2} \mathrm{AlCl}$ & 13 \\
2 & 70 & 20 & DCM & 300 & - & - \\
3 & 160 & 2 & DMF & 300 & - & - \\
4 & 230 & 7 & DMF & 300 & - & - \\
5 & 230 & 20 & DMF & 300 & - & - \\
6 & 230 & 20 & DMF & 300 & Eu(fod) ${ }_{3}{ }^{\mathrm{a}}$ & 60 \\
\hline
\end{tabular}

${ }^{\text {a}}$ Fod refers to 6,6,7,7,8,8,8-heptafluoro-2,2-dimethyl-3,5-octanedionate on the Claisen rearrangement with thermal conditions in the microwave-assisted synthesis of the compound 11 [14]. Interestingly, Eu(fod) ${ }_{3}$ had a marked effect upon 8-allyl-7hydroxy-4-(3-methoxyphenyl)-2H-chromen-2-one (11) formation. Thus, heating in microwaves 7 -allyloxyneoflavone 10 at $230{ }^{\circ} \mathrm{C}$ in DMF for $20 \mathrm{~h}$ recovered starting material only, while the addition of $\mathrm{Eu}(\mathrm{fod})_{3}(9 \mathrm{~mol} \%)$ gave rise to $60 \%$ yield of C-allylated product 11 (Table 1), set for the further step in the olefin cross-metathesis reaction.

${ }^{1} \mathrm{H}$ NMR spectrum of 8-allyl-7-hydroxyneoflavone $\mathbf{1 1}$ shows the signal at $8.12 \mathrm{ppm}$ assigned to $\mathrm{OH}$, while the absence of $\mathrm{H} 8$, the doublet at $3.63 \mathrm{ppm}$, the multiplets at 5.00-5.12 ppm and 5.95-6.11 ppm indicate the CO-bond cleavage and the substitution of $\mathrm{C}-8$ with allyl group.

Acetylation of $\mathbf{1 1}$ with acetyl chloride was then undertaken to facilitate the product solubility in the olefin crossmetathesis reaction conditions (Scheme 3). It furnished the acetylated product 12 in $79 \%$ yield. The singlet at $2.35 \mathrm{ppm}$ in the ${ }^{1} \mathrm{H}$ NMR spectrum (acetone- $d_{6}$ ) of $\mathbf{1 2}$ and the absence of the singlet at $8.12 \mathrm{ppm}$ assigned to $\mathrm{OH}$ in the ${ }^{1} \mathrm{H}$ NMR spectrum (acetone- $d_{6}$ ) of 8-allyl-7-hydroxy-4-(3methoxyphenyl)-2H-chromen-2-one (11) are associated with the $\mathrm{OH}$ substitution with acetyl group.

With 7-acetoxyneoflavone $\mathbf{1 2}$ in hand, its further elaboration to the 3,3'-dimethylallyl derivative $\mathbf{3}$ was pursued through the olefin cross-metathesis reaction with the secondgeneration Grubbs catalyst (Scheme 4).

Notably, Pahari et al. reported that attempted the olefin cross-metathesis reaction in the presence of the second-generation Grubbs catalyst failed in the conditions identical to those reported by Hastings et al. [15, 16]. We envisaged that the olefin cross-metathesis reaction with 8-allylneoflavone $\mathbf{1 2}$ would proceed in relatively low yield of the target 3,3'-dimethylallyl product 3 in view of the steric hindrance factor that requires a higher temperature for this reaction. Therefore, in contrast with the approach reported by Tischer and Metz (2-methyl-2-butene, the second-generation Grubbs catalyst ( $1 \mathrm{~mol} \%$ ), benzene, room temperature, overnight, $73 \%$ yield for a mixture) the suggested rapid heating in microwaves $\left(100{ }^{\circ} \mathrm{C}, 300 \mathrm{~W}\right)$ of the 8-allylneoflavone 12, 2-methyl-2-butene, the second-generation Grubbs catalyst ( $5 \mathrm{~mol} \%$ ) in DCM under argon allowed us to overcome this problem successively to isolate the pivotal product 3 in $65 \%$ yield. The demonstrated 6 steps synthesis of the target compound 3 proceeded in an overall yield of $5 \%$.

The ${ }^{1} \mathrm{H}$ NMR spectrum (acetone- $d_{6}$ ) of 3,3'-dimethylallyl product 3 reveals two singlets at $1.69 \mathrm{ppm}$ and $1.87 \mathrm{ppm}$ assigned to two $\mathrm{CH}_{3}$ groups in addition to the absence of the corresponding multiplet at 5.01-5.14 ppm assigned to the olefinic $=\mathrm{CH}_{2}$ moiety in the ${ }^{1} \mathrm{H}$ NMR spectrum (acetone- $\left.d_{6}\right)$ of the compound $\mathbf{1 2}$.

\section{Conclusion}

The prenylneoflavone system assembling has been achieved in six steps in 5\% overall yield using the Pechmann condensation with the sequence of the Mitsunobu reaction/Claisen

Scheme 4

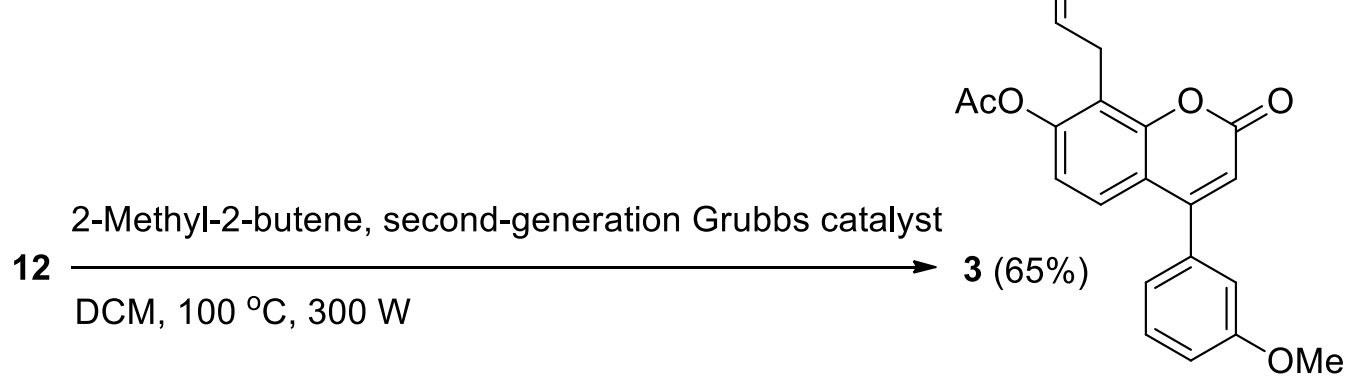


rearrangement/olefin cross-metathesis reaction. It allowed extending the substrate scope for abovementioned prenylation approach with regard to the prenylneoflavone system assembling starting from phenols. The present approach will be useful in medicinal chemistry to modulate the bioactivity of drug candidates through the structural modification of oxygen-containing heterocycles with the lipophilic prenyl group. It is of particular interest for the creation of protease inhibitors against the $\mathrm{CoV}$ infection.

\section{Experimental}

Reaction progress and identity of obtained compounds were monitored by TLC on Merck 60 F254 silica gel plates. NMR spectra were recorded on Bruker Avance 300 (spectrometer frequency for ${ }^{1} \mathrm{H}: 300 \mathrm{MHz}$ ) spectrometer at $298 \mathrm{~K}$ in DMSO- $d_{6}, \mathrm{CDCl}_{3}$, and acetone- $d_{6}$. The TMS signal was used as an internal standard. The results of elemental analyses for $\mathrm{C}, \mathrm{H}$, and $\mathrm{N}$ were found to be in good agreement $(0.2 \%)$ with the calculated values. Compound $\mathbf{8}$ was synthesized according to a procedure published in the literature [12]. All reagents and solvents used were of commercial quality without further purification.

Ethyl 3-(3-methoxyphenyl)-3-oxopropanoate (9) Diethyl carbonate (4.94 g, $41.85 \mathrm{mmol}, 1.03$ equiv) was added dropwise to the solution of $5.07 \mathrm{~g}$ sodium hydride (211.28 mmol, 5.2 equiv) and $6.02 \mathrm{~g} \mathrm{3-methoxyacetophe-}$ none $\left(7,40.63 \mathrm{mmol}, 1\right.$ equiv) in $50 \mathrm{~cm}^{3}$ distilled THF under argon. The reaction mixture was then stirred at reflux for $6 \mathrm{~h}$. The resulting mixture was cooled down to the room temperature, a beige precipitate was observed. It was then filtered out and the filtrate was acidified with $\mathrm{HCl}(15 \%$ aq) and extracted with EtOAc $\left(3 \times 50 \mathrm{~cm}^{3}\right)$. The organic layer was washed with brine and dried over anhydrous $\mathrm{MgSO}_{4}$. The solvent was removed under reduced pressure, and the residue was purified by silica gel column chromatography (cyclohexane/EtOAc, 8:2) to give 9. Brown oil; yield: $3.72 \mathrm{~g}$ (40\%); b.p.: $123^{\circ} \mathrm{C} / 0.3$ Torr) (Ref. [17]. $123^{\circ} \mathrm{C} / 0.3$ Torr); ${ }^{1} \mathrm{H}$ NMR of keto form: $\left(\mathrm{CDCl}_{3}, 300 \mathrm{MHz}\right): \delta=1.24(\mathrm{t}$, $\left.3 \mathrm{H}, J=6 \mathrm{~Hz}, \mathrm{CH}_{3} \mathrm{CH}_{2}\right), 3.84\left(\mathrm{~s}, 3 \mathrm{H}, \mathrm{CH}_{3} \mathrm{O}\right), 3.96(\mathrm{~s}, 2 \mathrm{H}$, $\left.\mathrm{CH}_{2}\right), 4.20\left(\mathrm{q}, 2 \mathrm{H}, J=9 \mathrm{~Hz}, \mathrm{CH}_{3} \mathrm{CH}_{2}\right), 7.10-7.14(\mathrm{~m}, 1 \mathrm{H}$, $\mathrm{H} 2^{\prime}$ ); 7.34-7.39 (m, 1H, H5'), 7.46-7.50 (m, 2H, H4', H6') ppm; ${ }^{1} \mathrm{H}$ NMR of enol form $\left(\mathrm{CDCl}_{3}, 300 \mathrm{MHz}\right): \delta=1.32(\mathrm{t}$, $\left.3 \mathrm{H}, J=6 \mathrm{~Hz}, \mathrm{CH}_{3} \mathrm{CH}_{2}\right), 3.82\left(\mathrm{~s}, 3 \mathrm{H}, \mathrm{CH}_{3} \mathrm{O}\right), 4.25(\mathrm{q}, 2 \mathrm{H}$, $\left.J=9 \mathrm{~Hz}, \mathrm{CH}_{3} \mathrm{CH}_{2}\right), 5.64(\mathrm{~s}, 1 \mathrm{H},=\mathrm{CH}-), 6.97-7.01(\mathrm{~m}, 1 \mathrm{H}$, H2'), 7.30-7.33 (m, 3H, H4', H5', H6'), 12.57 (s, 1H, OH) ppm [18].

7-Hydroxy-4-(3-methoxyphenyl)-2H-chromen-2-one (8) To a stirred solution of $0.803 \mathrm{~g} 9$ (3.62 mmol, 1 equiv) and $0.52 \mathrm{~g}$ resorcinol ( $4.71 \mathrm{mmol}, 1.3$ equiv) in $8 \mathrm{~cm}^{3} \mathrm{EtOH}$ was added dropwise $5 \mathrm{~cm}^{3}$ sulfuric acid over $30 \mathrm{~min}$, followed by the heating of the reaction mixture at $65{ }^{\circ} \mathrm{C}$ for $7 \mathrm{~h}$. The reaction mixture was then cooled down to the room temperature and poured into $50 \mathrm{~cm}^{3}$ of distilled water and then extracted with chloroform $\left(3 \times 50 \mathrm{~cm}^{3}\right)$. The solvent was removed under reduced pressure; the viscous brown oil was dissolved in the $0.5 \mathrm{M}$ solution of potassium hydroxide $\left(100 \mathrm{~cm}^{3}\right)$ and extracted with DCM $\left(3 \times 50 \mathrm{~cm}^{3}\right)$. The aqueous layer was acidified with $\mathrm{HCl}(15 \%$ aq) until $\mathrm{pH} 1$ and then extracted with chloroform $\left(3 \times 50 \mathrm{~cm}^{3}\right)$. The organic layer was dried over anhydrous $\mathrm{MgSO}_{4}$, and the solvent was removed under reduced pressure. The oil residue was recrystallized from $\mathrm{MeOH}$ to give 8 . White solid; yield: $0.50 \mathrm{~g}$ (52\%); m.p.: $242{ }^{\circ} \mathrm{C}$ (Ref. [12]. 241-243 ${ }^{\circ} \mathrm{C}$ ).

7-Allyloxy-4-(3-methoxyphenyl)-2H-chromen-2-one $\left(10, \mathrm{C}_{19} \mathrm{H}_{16} \mathrm{O}_{4}\right)$ To a stirred solution of $0.88 \mathrm{~g} 8$ (1 equiv, $3.28 \mathrm{mmol}), 1.07 \mathrm{~g}$ triphenylphosphine (1.24 equiv, $4.07 \mathrm{mmol}$ ) and $0.4 \mathrm{~cm}^{3}$ allyl alcohol (1.79 equivalents, $5.87 \mathrm{mmol}$ ) in $20 \mathrm{~cm}^{3}$ distilled THF was added dropwise a solution of $1.10 \mathrm{~cm}^{3}$ diisopropyl azodicarboxylate (1.71 equiv, $5.61 \mathrm{mmol}$ ) in $20 \mathrm{~cm}^{3}$ distilled THF under argon at $0{ }^{\circ} \mathrm{C}$ over $10 \mathrm{~min}$. The reaction was stirred at room temperature overnight. Then it was quenched with brine and washed with it several times until no precipitate formed. The aqueous layer was extracted with $\mathrm{Et}_{2} \mathrm{O}\left(3 \times 50 \mathrm{~cm}^{3}\right)$ and the layers were separated. The combined organics were dried over anhydrous $\mathrm{MgSO}_{4}$ and the volatiles were removed under reduced pressure. The crude product was purified by silica gel column chromatography (cyclohexane/ $\mathrm{Et}_{2} \mathrm{O}$, from 8:2 to 7:3) to give 10. White solid; yield: $0.79 \mathrm{~g}(78 \%) ;{ }^{1} \mathrm{H}$ NMR ( $\left.\mathrm{CDCl}_{3}, 300 \mathrm{MHz}\right): \delta=3.86\left(\mathrm{~s}, 3 \mathrm{H}, \mathrm{CH}_{3} \mathrm{O}\right), 4.61(\mathrm{~d}$, $2 \mathrm{H}, J=5.7 \mathrm{~Hz}, \mathrm{OCH}_{2}$ ), 5.34-5.45 (ddt, $2 \mathrm{H}, J=44.5,17.2$, $\left.1.7 \mathrm{~Hz},=\mathrm{CH}_{2}\right), 6.05(\mathrm{ddt}, 1 \mathrm{H}, J=17.3,10.5,5.3 \mathrm{~Hz},=\mathrm{CH}-$ ), 6.23 (s, 1H, H3), 6.81 (dd, 1H, $J=8.9,2.6 \mathrm{~Hz}, \mathrm{H} 8), 6.90$ (d, 1H, $\left.J=2.5 \mathrm{~Hz}, \mathrm{H6}^{\prime}\right), 6.95$ (t, 1H, $\left.J=2.1 \mathrm{~Hz}, \mathrm{H} 2^{\prime}\right), 7.03$ (td, 2H, $\left.J=11.5,2.7 \mathrm{~Hz}, \mathrm{H6}, \mathrm{H} 5^{\prime}\right), 7.42$ (dd, 2H, $J=11.5$, $2.7 \mathrm{~Hz}, \mathrm{H} 4$ ', H5) ppm; ${ }^{13} \mathrm{C} \mathrm{NMR}\left(\mathrm{CDCl}_{3}, 75 \mathrm{MHz}\right)$ : $\delta=53.58,69.82,101.98,111.83,112.57,112.82,114.08$, $114.99,118.58,120.70,128.05,129.97,132.17,137.35$, $155.67,156.67,160.31,161.22,162.24 \mathrm{ppm}$.

8-Allyl-7-hydroxy-4-(3-methoxyphenyl)-2H-chromen-2-one $\left(11, \mathrm{C}_{19} \mathrm{H}_{16} \mathrm{O}_{4}\right)$ To a solution of $0.65 \mathrm{~g} 10$ (1 equiv, $2.11 \mathrm{mmol})$ in $12 \mathrm{~cm}^{3}$ DMF was added $0.22 \mathrm{~g} \mathrm{Eu}(\text { fod })_{3}$ (9 mol\%). The vial was sealed and heated at $230{ }^{\circ} \mathrm{C}$ under microwaves for $20 \mathrm{~h}$ (START SYNTH Microwave synthesis labstation, $300 \mathrm{~W})$. The reaction mixture was then washed with the aqueous $\mathrm{HCl}(15 \% \mathrm{aq})\left(3 \times 50 \mathrm{~cm}^{3}\right)$ and extracted with EtOAc $\left(3 \times 40 \mathrm{~cm}^{3}\right)$ and the layers were separated. The combined organics were dried over anhydrous $\mathrm{MgSO}_{4}$ and the volatiles were removed under reduced pressure. The viscous brown oil was dissolved in the $0.5 \mathrm{M}$ solution of 
potassium hydroxide $\left(100 \mathrm{~cm}^{3}\right)$ and extracted with DCM $\left(6 \times 30 \mathrm{~cm}^{3}\right)$. The aqueous layer was acidified with $\mathrm{HCl}$ $(15 \% \mathrm{aq})$ and extracted with chloroform $\left(5 \times 40 \mathrm{~cm}^{3}\right)$. The organic layer was dried over anhydrous $\mathrm{MgSO}_{4}$, the solvent was removed under reduced pressure to give. The crude product was purified by silica gel column chromatography (cyclohexane/Et $2 \mathrm{O}$, from 8:2 to 7:3) to give 11. Light yellow solid; yield: $0.39 \mathrm{~g}(60 \%) ;{ }^{1} \mathrm{H}$ NMR (acetone- $d_{6}, 300 \mathrm{MHz}$ ): $\delta=3.63\left(\mathrm{~d}, 2 \mathrm{H}, J=6.3 \mathrm{~Hz},-\mathrm{CH}_{2}-\right), 3.89\left(\mathrm{~s}, 3 \mathrm{H}, \mathrm{CH}_{3} \mathrm{O}\right)$, $5.00-5.12\left(\mathrm{dd}, 2 \mathrm{H}, J=10.0,17.1 \mathrm{~Hz},=\mathrm{CH}_{2}\right), 5.95-6.11(\mathrm{~m}$, $1 \mathrm{H},=\mathrm{CH}-), 6.12(\mathrm{~s}, 1 \mathrm{H}, \mathrm{H} 3), 6.92\left(\mathrm{~d}, 1 \mathrm{H}, J=8.9 \mathrm{~Hz}, \mathrm{H} 6^{\prime}\right)$, 7.01-7.16 (m, 3H, H2', H6, H5), 7.25 (d, 1H, $J=8.8 \mathrm{~Hz}$, $\mathrm{H}^{\prime}$ ), 7.47 (t, 1H, $\left.J=8.1 \mathrm{~Hz}, \mathrm{H} 5^{\prime}\right), 8.12(\mathrm{~s}, 1 \mathrm{H}, \mathrm{OH}) \mathrm{ppm}$; ${ }^{13} \mathrm{C}$ NMR (acetone- $d_{6}, 76 \mathrm{MHz}$ ): $\delta=26.84,55.46,102.49$, $110.52,111.63,112.58,113.65,114.69,114.97,121.78$, $125.84,129.84,135.39,137.31,153.79,156.00,158.81$, $159.94,160.20 \mathrm{ppm}$.

\section{8-Allyl-4-(3-methoxyphenyl)-2-oxo-2H-chromen-7-yl acetate} $\left(12, \mathrm{C}_{21} \mathrm{H}_{18} \mathrm{O}_{5}\right)$ To a stirred solution of the crude product of 11 ( 1 equiv, $0.33 \mathrm{~g}, 1.08 \mathrm{mmol}$ ) in $1 \mathrm{~cm}^{3}$ pyridine was added $0.46 \mathrm{~cm}^{3}$ acetyl chloride (6 equiv). The reaction mixture was stirred at reflux for $6 \mathrm{~h}$. The mixture was poured into distilled water and then extracted with DCM. The organic layer was dried over anhydrous $\mathrm{MgSO}_{4}$ and the solvent removed under reduced pressure. The brown oil was purified by silica gel column chromatography (cyclohexane/EtOAc, 8:2) to give 12. Brown solid; yield: $0.3 \mathrm{~g}(79 \%) ;{ }^{1} \mathrm{H}$ NMR (acetone- $\left.d_{6}, 300 \mathrm{MHz}\right): \delta=2.35\left(\mathrm{~s}, 3 \mathrm{H}, \mathrm{CH}_{3} \mathrm{CO}\right), 3.57$ (dt, $\left.2 \mathrm{H}, J=6.3,1.6 \mathrm{~Hz},-\mathrm{CH}_{2}-\right), 3.88\left(\mathrm{~s}, 3 \mathrm{H}, \mathrm{CH}_{3} \mathrm{O}\right), 5.01-5.14$ (qq, $\left.2 \mathrm{H}, J=6.3,1.5 \mathrm{~Hz},=\mathrm{CH}_{2}\right), 5.83-6.04(\mathrm{~m}, 1 \mathrm{H},=\mathrm{CH}-$ ), 6.33 (s, 1H, H3), 7.07-7.15 (m, 4H, H2', H6', H6, H5), 7.36-7.59 (m, 2H, H4', H5') ppm; ${ }^{13} \mathrm{C}$ NMR (acetone- $d_{6}$, $76 \mathrm{MHz}): \delta=20.55,27.72,55.46,113.88,114.01,115.27$, $115.60,117.36,118.98,120.64,121.27,125.45,129.99$, $134.55,137.76,151.86,153.40,155.31,159.29,160.60$, $169.05 \mathrm{ppm}$.

4-(3-Methoxyphenyl)-8-(3-methylbut-2-en-1-yl)-2-oxo-2Hchromen-7-yl acetate $\left(3, \mathrm{C}_{23} \mathrm{H}_{22} \mathrm{O}_{5}\right)$ To a solution of $0.08 \mathrm{~g}$ 12 (1 equiv, $0.24 \mathrm{mmol}$ ) and $0.26 \mathrm{~cm}^{3}$ 2-methyl-2-butene $(2.44 \mathrm{mmol})$ was added $0.12 \mathrm{~g}$ of the second-generation Grubbs catalyst (5 mol\%) in distilled DCM under argon. The mixture was placed into START SYNTH Microwave synthesis labstation for $30 \min \left(100^{\circ} \mathrm{C}, 300 \mathrm{~W}\right)$. The solvent was removed under reduced pressure, and the product purified by silica gel column chromatography (cyclohexane/EtOAc 9:1) to give 3. Brown oil; yield: $0.06 \mathrm{~g}(65 \%) ;{ }^{1} \mathrm{H}$ NMR (acetone- $\left.d_{6}, 300 \mathrm{MHz}\right): \delta=1.69\left(\mathrm{~s}, 3 \mathrm{H}, \mathrm{CH}_{3}\right), 1.87(\mathrm{~s}, 3 \mathrm{H}$, $\mathrm{CH}_{3}$ ), 2.38 (s, $3 \mathrm{H}, \mathrm{CH}_{3} \mathrm{CO}$ ), 3.52 (d, $2 \mathrm{H}, J=7.1 \mathrm{~Hz},-\mathrm{CH}_{2}-$ ), 3.89 (s, $\left.3 \mathrm{H}, \mathrm{CH}_{3} \mathrm{O}\right), 5.19$ (t, $\left.1 \mathrm{H}, J=7.1 \mathrm{~Hz},-\mathrm{CH}-\right), 6.33$ (s, 1H, H3), 7.02-7.20 (m, 4H, 2', H6', H6, H5), 7.40 (dd, 1H, $\left.J=8.8,5.8 \mathrm{~Hz}, \mathrm{H} 4^{\prime}\right), 7.44-7.57$ (m, 1H, H5') ppm; ${ }^{13} \mathrm{C} \mathrm{NMR}$ (acetone- $d_{6}, 76 \mathrm{MHz}$ ): $\delta=17.06,20.51,26.61,54.09,54.90$, $113.87,115.25,116.77,118.698,120.63,121.55,125.21$, $126.53,127.00,130.63,132.79,136.76,151.61,152.82$, $155.35,159.34,160.02,168.97 \mathrm{ppm}$.

Acknowledgements Oleg Lozinski thanks Erasmus Mundus and Dr. Aline Marighetto for providing with such a brilliant opportunity to broaden horizons in Organic Chemistry. We would like to thank Dr. V. Ishchenko and Dr. S. Vasylevskyi for their support.

\section{References}

1. Lee JJ, Choi HJ, Yun M, Kang Y, Jung JE, Ryu Y, Kim TY, Cha YJ, Cho HS, Min JJ, Chung CW, Kim HS (2015) Angew Chem Int Ed 54:12020

2. Kloog Y, Cox AD (2004) Semin Cancer Biol 14:253

3. Yazaki K, Sasaki KY, Tsurumaru (2009) Phytochemistry 70:1739

4. Keiler AM, Zierau O, Kretzschmar G (2013) Planta Med 79:576

5. Park JY, Yuk HJ, Ryu HW, Lim SH, Kim KS, Park KH, Ryu YB, Lee WS (2017) J Enzyme Inhib Med Chem 32:504

6. Turk B (2006) Nat Rev Drug Discov 5:785

7. Zhou P, Yang X, Wang X, Hu B, Zhang L, Zhang W, Si H, Zhu Y, Li B, Huang C, Chen H, Chen J, Luo Y, Guo H, Jiang R, Liu M, Chen Y, Shen X, Wang X, Zheng X, Zhao K, Chen Q, Deng F, Liu L, Yan B, Zhan F, Wang Y, Xiao G, Shi Z (2020) Nature 579:270

8. Lozinski O, Bennetau-Pelissero C, Shinkaruk S (2017) Chem Select 2:6577

9. Schultze C, Schmidt B (2018) J Org Chem 83:5210

10. Tischer S, Metz P (2007) Adv Synth Catal 349:147

11. Lozinski OA, Shokol TV, Khilya VP (2013) Monatsh Chem 144:217

12. Chen Y, Wang S, Xu X, Liu X, Yu M, Zhao S, Liu S, Qiu Y, Zhang T, Liu B, Zhang G (2013) J Med Chem 56:4671

13. Sonnenberg FM (1970) J Org Chem 35:3166

14. Daskiewicz JB, Bayet C, Barron D (2002) Tetrahedron 58:3589

15. Pahari P, Rohr J (2009) J Org Chem 74:2750

16. Hastings JM, Hadden MK, Blagg BS (2008) J Org Chem 73:369

17. Nakano J, Katagiri N, Kato T (1982) Chem Pharm Bull 30:2590

18. Shin H, Choi BS, Lee KK, Choi H, Chang JH, Lee KW, Nam DH, Kim N (2004) Synthesis 16:2629

Publisher's Note Springer Nature remains neutral with regard to jurisdictional claims in published maps and institutional affiliations. 